\title{
THE ACCUMULATION OF RADIOACTIVE CAESIUM IN CRABS
}

\author{
By G. W. BRYAN \\ The Plymouth Laboratory
}

(Text-figs. $\mathrm{I}-7$ )

The amount of caesium in sea water is very small, and a value of $0 \cdot 4-\mathrm{I} \cdot 3 \mu \mathrm{g} / 1$. has been given by Ishibashi \& Hara (1959). It has been found in experiments with the fission product ${ }^{137} \mathrm{Cs}$ that $\mathrm{Cs}$ can penetrate into and is concentrated by marine animals (Chipman, 1960). For instance, after long exposure to ${ }^{137} \mathrm{Cs}$, the prawn Palaemonetes pugio showed a concentration factor of about 25. The majority of experiments on the penetration of Cs into tissues have been carried out in vertebrates. Lubin \& Schneider (1957) demonstrated that almost all of the $\mathrm{K}$ in isolated frog sartorius muscle can be replaced by $\mathrm{Rb}$ or Cs with only slight accumulation of $\mathrm{Na}$. In competition experiments, with equal external concentrations, the steady-state level for tissue Cs was distinctly lower than for K. Using radioactive isotopes, Mullins (1959) has measured the relative permeability of frog sartorius muscle to alkali cations. The order of permeabilities is $\mathrm{K}>\mathrm{Rb}>\mathrm{Cs}>\mathrm{Na}$. Relman, Lambie, Burrows \& Roy (1957) found that in young rats the muscle cells accumulate alkali metals, introduced by feeding, in order of preference $\mathrm{Cs}>\mathrm{Rb}>\mathrm{K}$. The tissue/ plasma concentration ratio for $\mathrm{Cs}$ which was finally reached was more than 4.5 times that for $\mathrm{K}$. This fact was given as evidence against the normal uptake of $\mathrm{K}$ by tissues being solely the result of passive movements along an electrical gradient produced by a 'sodium pump'. Generally the evidence indicates that $\mathrm{Cs}$ behaves or is treated by tissues in a way which, except in degree, is similar to $\mathrm{K}$.

The accumulation of radioactive Cs has been studied in six species of crabs. Much of the work has been carried out using Carcinus maenas (L.). In addition, three other members of the family Portunidae have been examined, viz. Portunus puber (L.), P. depurator (L.) and Polybius henslowi Leach. Cancer pagurus L. and Corystes cassivelaunus (Pennant) have also been used. An indication of the relative permeability of the body surfaces of different crabs to salts was given by Margaria (I93I) who followed the fall in blood osmotic pressure of animals placed in dilute sea water. His results showed that both species of Portunus are stenohaline while Carcinus is euryhaline. The order of permeability of the body surface is $P$. depurator $>P$. puber $>$ Carcinus. Nagel (1934) showed that the stenohaline Portunus holsatus is much more permeable to iodide than the more euryhaline Carcinus and Cancer. Polybius and Corystes 
are probably stenohaline crabs. Accurate analyses of the inorganic constituents of the blood and urine of Carcinus were made by Webb (1940). He concluded that the maintenance of $\mathrm{K}$ in the blood at a level rather greater than that in sea water is due to active absorption of $\mathrm{K}$ over the body surface coupled with the excretion of urine containing less $\mathrm{K}$ than the blood. A similar regulation of $\mathrm{K}$ was found in Cancer, Portunus puber and P. depurator by Robertson (1939, 1953). The maintenance of the high $\mathrm{K}$ content of Carcinus muscle was studied by Shaw (1958), who found that within the limits of error K was distributed passively across the fibre membrane according to the electrochemical gradient. He suggests that there may be a very small amount of active $\mathrm{K}$ uptake by muscle fibres particularly at low blood concentrations.

The accumulation of trace amounts of $\mathrm{Cs}$ is of interest when the biological aspects of radioactive waste disposal are considered. From this point of view the isotope ${ }^{137} \mathrm{Cs}$ is most important because it has a half-life of 30 years. In a natural environment an isotope such as ${ }^{137} \mathrm{Cs}$ can enter the crab by way of the body surface or via the gut either by feeding or drinking. Most of the experiments to be described were carried out on starved animals. As drinking in intermoult crabs is not recognized as in any sense a regular process, it is assumed that most of the Cs must enter starved animals through the gills. Some experiments have been carried out in which fed animals were used and the absorption of radioactive $\mathrm{Cs}$ from food has been examined. The relationship between the behaviour of $\mathrm{Cs}$ and $\mathrm{K}$ ions has been studied by comparing the ways in which crabs take up the radioactive isotopes ${ }^{134} \mathrm{Cs}$ and ${ }^{42} \mathrm{~K}$. At equilibrium the levels attained by these isotopes in blood and tissues have been compared with the inactive $\mathrm{K}$ concentrations. A comparison of the excretion of ${ }^{134} \mathrm{Cs}$ and inactive $\mathrm{K}$ has also been made.

\section{MATERIALS AND METHODS}

Carcinus maenas, Portunus puber and Cancer pagurus were collected from the shore in Plymouth Sound. Portunus depurator and Corystes cassivelaunus were trawled from deeper water and Polybius henslowi was taken in hand-nets over deep water in the Bay of Biscay. Nearly always male animals were used.

Isotopes were obtained from the Radiochemical Centre, Amersham. ${ }^{134} \mathrm{Cs}$ was received as $0.2 \mathrm{~g}$ of carbonate having an activity of $\mathrm{I} \cdot 0 \mathrm{mc} .{ }^{42} \mathrm{~K}$ was received as $\mathrm{I} \cdot \mathrm{O} \mathrm{g}$ of carbonate having an initial activity of about $2 \mathrm{mc}$. The carbonates were converted to chlorides with dilute hydrochloric acid and after evaporation $100 \mathrm{ml}$. stock solutions were made up with distilled water.

For isotope experiments partitioned glass tanks of about 5 and Iol. capacity were used. Each was covered with a close-fitting lid through which passed one tube for aeration and a second tube carrying exhaust air outside the laboratory. About 21 . of experimental medium were allowed per animal, and in long experiments this was changed at intervals. The media used were normal 
artificial sea water and artificial sea water with half the normal $\mathrm{K}$ content. Artificial sea water $(\mathrm{Cl} \%=\mathrm{I} \%)$ was prepared according to the tables of Barnes (1954). In ${ }^{134} \mathrm{Cs}$-uptake experiments a sea water activity of $5 \mu \mathrm{C} / 1$. was used and with ${ }^{42} \mathrm{~K}$ the initial activity was about $100 \mu \mathrm{C} / 1$. These isotope concentrations gave the sea water a Cs level of about $0.003 \mathrm{~mm} / 1$. or an additional $\mathrm{K}$ concentration of $0.3-0.4 \mathrm{~mm} / 1$. The work was done at a room temperature of $16-18^{\circ} \mathrm{C}$ or in a regulated tank at $17^{\circ} \mathrm{C}$.

Prior to uptake experiments animals were allowed 2 days to become equilibrated with inactive artificial sea water. To measure the activity of a whole animal it was drained of medium, placed in a $200 \mathrm{ml}$. beaker and counted within a ring of $8 \gamma$-sensitive GM tubes (2oth-Century type $\mathrm{G}$. IO. Pb). This equipment was used by Fretter (1955). At intervals samples of medium were counted in the same beaker, and any depletion of activity was corrected by changing the solution.

Urine was taken from the excretory organ opening with a glass pipette after the operculum had been raised with a blunt needle. Blood was taken with a glass pipette from the region between the carapace and a rear walking leg. Samples of whole blood and of centrifuged blood were both used and compared. For radioactive estimations blood or urine was weighed on an aluminium planchet and the dried sample counted beneath the end window of a $\gamma$-scintillation counter (type II86A). Other samples were diluted for K estimation by flame photometry.

Tissues for radioactive and $\mathrm{K}$ analysis were dissected out and dried on filter paper. Samples were not washed because Cs or K might have been selectively removed. Normally about $0.3 \mathrm{~g}$ of tissue was needed. Muscle was taken from the coxopodite segments of the walking legs and chelae. The water content of each tissue sample was determined in a $25 \mathrm{ml}$. conical 'Pyrex' flask. Up to $5 \mathrm{ml}$. of concentrated nitric acid were added to the dry sample in I ml. lots and slowly evaporated off over an electric fire element. Hot distilled water was used to dissolve the residue, occasionally with the help of a drop of acid. Blank samples were also prepared. Tissue radioactivity was measured on a Io ml. sample placed below the end window of the $\gamma$-scintillation counter. The rest of the sample was further diluted for $\mathrm{K}$ estimation. In order to save time during experiments with ${ }^{42} \mathrm{~K}$ the tissue water content was not determined.

In graphs for isotope uptake the activity of the whole animal, blood, urine and tissues is expressed as a concentration factor and is plotted against time in hours. The concentration factor is the ${ }^{134} \mathrm{Cs}$ activity, ${ }^{42} \mathrm{~K}$ activity or the inactive $\mathrm{K}$ concentration per $\mathrm{kg}$ of tissue divided by the corresponding concentration per $\mathrm{kg}$ of sea water. Where uptake of isotope was followed by loss in inactive sea water, the results are still expressed as concentration factors relative to the activity of the sea water during uptake. 


\section{The effect of caesium on Carcinus \\ RESULTS}

Preliminary experiments indicated that Carcinus would die within 5 days if more than $20 \%$ of the $\mathrm{K}$ in artificial sea water was replaced by Cs. When $20 \%$ Cs was used animals lived for up to 3 weeks and for a longer period in I0 \% Cs. As Carcinus is able to live fairly indefinitely in artificial sea water with $50 \% \mathrm{~K}$ but no $\mathrm{Cs}$ it would appear that $\mathrm{Cs}$ must be toxic at relatively high external concentrations. However, there is no reason to suspect that the $0.003 \mathrm{~mm} / 1$. added with ${ }^{134} \mathrm{Cs}$ would have any effect on the animal. In experiments with Galathea squamifera and Palaemon serratus, which are unpublished, it has been shown that there is no significant difference between the rates at which ${ }^{134} \mathrm{Cs}$ and the carrier free isotope ${ }^{137} \mathrm{Cs}$ are accumulated.

Some vertebrate tissues are able to function in the presence of large amounts of Cs. Relman and his co-workers (I957) found that in rats, where the normal level of $\mathrm{K}$ in muscle was $170 \mathrm{mM} / 1 . \mathrm{H}_{2} \mathrm{O}$, concentrations of $\mathrm{Cs}$ as high as I IO $\mathrm{mM} / 1 . \mathrm{H}_{2} \mathrm{O}$ and $\mathrm{K}$ concentrations as low as $50 \mathrm{~mm} / 1 . \mathrm{H}_{2} \mathrm{O}$ could be achieved before the animals died.

\section{Uptake of ${ }^{134} \mathrm{Cs}$ and ${ }^{42} \mathrm{~K}$ by whole animals}

Curves showing the increase in the ${ }^{134} \mathrm{Cs}$ concentration factor with time are given for all six species in Fig. I A-C. Uptake of ${ }^{134} \mathrm{Cs}$ by whole animals is a slow process particularly in Carcinus. Analysis shows that most of the curves are roughly exponential in shape except over the first $50 \mathrm{~h}$ when uptake is more rapid. Comparable curves for the uptake of ${ }^{42} \mathrm{~K}$ are given in Fig. $2 \mathrm{~A}-\mathrm{C}$. These curves are almost totally exponential, particularly for $P$. puber and $P$. depurator. In Figs. I and 2 single curves are given for each species except when fairly wide variations were found such as in Cancer (Fig. I B). The results for all animals which approached equilibrium closely are given in Table I. As the rates of attainment of equilibrium in sea water containing ${ }^{134} \mathrm{Cs}$ are not constant they have been compared with those found with ${ }^{42} \mathrm{~K}$ in terms of the time taken to reach $50 \%$ of the concentration factor when equilibrium was substantially reached. The equilibrium concentration factors and weights of the animals are also given.

From the figures and table it is immediately obvious that ${ }^{42} \mathrm{~K}$ is accumulated far more quickly than ${ }^{134} \mathrm{Cs}$ in all species and that ${ }^{42} \mathrm{~K}$ equilibrium concentration factors are lower than those for ${ }^{134} \mathrm{Cs}$. Uptake of both isotopes is slowest in Carcinus where at equilibrium the concentration factors for ${ }^{134} \mathrm{Cs}$ are approximately double those for ${ }^{42} \mathrm{~K}$. In the other species this difference is less marked. In artificial sea water containing $50 \% \mathrm{~K}$ the whole Carcinus concentration factor for ${ }^{42} \mathrm{~K}$ is increased and a corresponding increase in the factor for ${ }^{134} \mathrm{Cs}$ is found. The times taken for both isotopes to reach virtual equilibrium in this solution are about the same as in normal artificial sea 
TABLE 1. TIMES TAKEN TO ATTAIN 50\% OF THE EQUILIBRIUM CONCENTRATION FACTORS FOR ${ }^{134} \mathrm{Cs}$ AND ${ }^{42} \mathrm{~K}$ IN WHOLE CRABS

(The figures are given as mean values with standard deviations.)

${ }^{134} \mathrm{Cs}$

No. of
animals
4
3
6
2
I
6
I

Equ

(g)

$4 \cdot 4$
C. maenas in $50 \% \mathrm{~K}$ artificial

sea water

Portunus pube

$P$. depurator

Polybius henslowi ${ }^{\star}$

Cancer pagurus

Corystes cassivelaumus
$8 \cdot 5+0 \cdot 6$

$8 \cdot 5 \pm 0.6$

$3 \cdot 1 \pm 0 \cdot 8$

$6 \cdot 6 \pm I \cdot 4$
$6 \cdot 5 \pm 0 \cdot 0$

$6.5 \pm 0$

$6 \cdot 0 \pm \mathrm{I} \cdot 4$

* These animals died after equilibrium appeared to have been reached.
${ }^{42} \mathrm{~K}$

\begin{tabular}{|c|c|c|c|}
\hline $\begin{array}{l}\text { No. of } \\
\text { animals }\end{array}$ & $\begin{array}{l}\text { Mean } \\
\text { weight } \\
\text { (g) }\end{array}$ & $\begin{array}{l}\text { Equilibrium } \\
\text { concentration } \\
\text { factor }\end{array}$ & $\begin{array}{l}\text { Time for } \\
50 \% \text { uptake } \\
\text { (h) }\end{array}$ \\
\hline 6 & 42 & $4.0 \pm 0.3$ & $19.0 \pm 6.0$ \\
\hline 2 & 27 & $8 \cdot 0 \pm 0.2$ & $17.5 \pm 2.5$ \\
\hline 4 & 44 & $5.9 \pm 0.7$ & $3 \cdot 1 \pm 0 \cdot 7$ \\
\hline 2 & 20 & $5.6 \pm 0.1$ & $2.5 \pm 0.5$ \\
\hline 2 & 9 & $4.2 \pm 0.2$ & $3 \cdot 2 \pm 0.2$ \\
\hline 2 & 28 & $3.9 \pm 0.2$ & $15.5 \pm 0.5$ \\
\hline 2 & IO & $3.6 \pm 0.1$ & $4 \cdot 2 \pm 1 \cdot 2$ \\
\hline
\end{tabular}



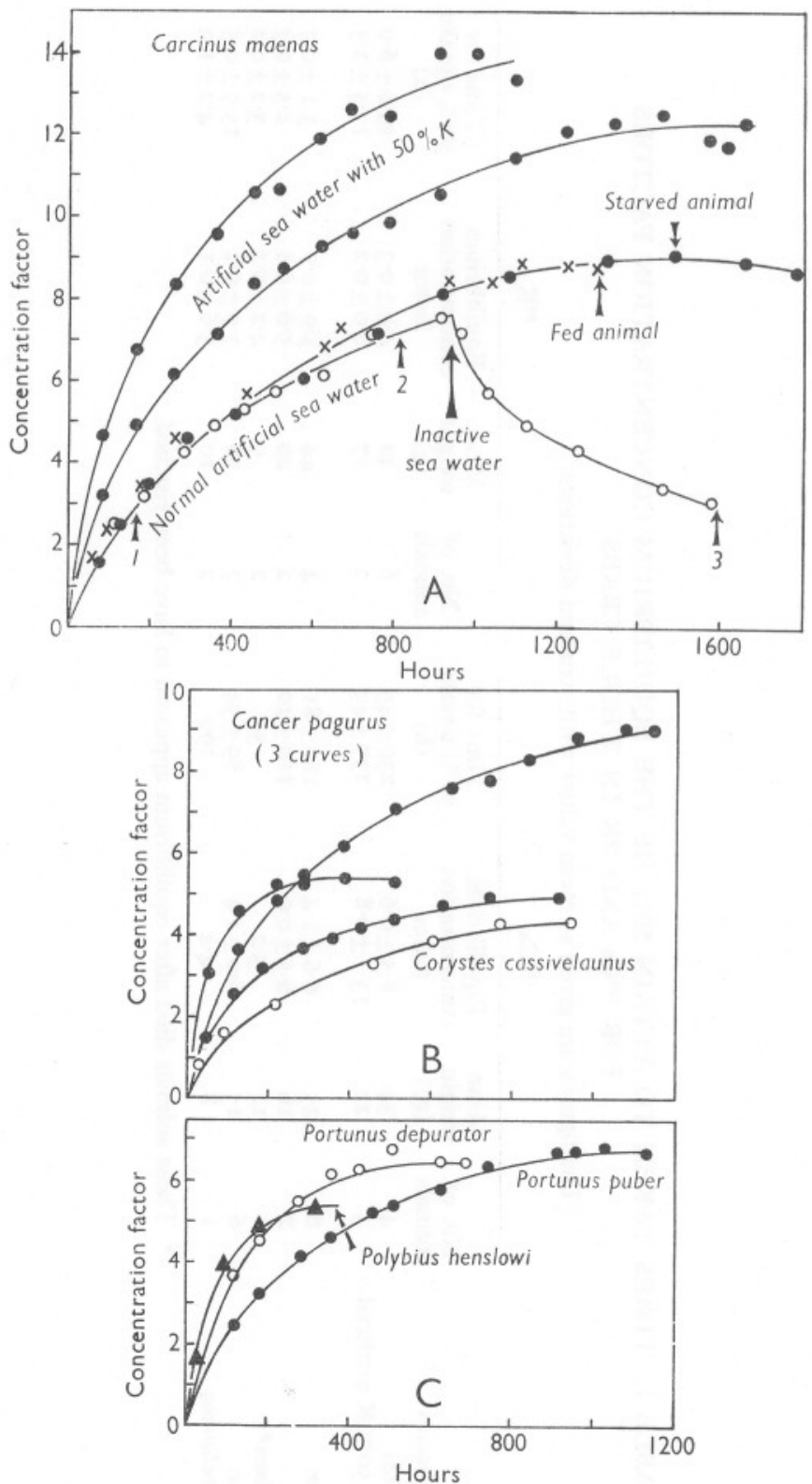

Fig. I A-C. Uptake of ${ }^{134} \mathrm{Cs}$ by whole crabs from artificial sea water. The concentration factor is the activity per $\mathrm{kg}$ whole crab divided by the activity per $\mathrm{kg}$ of sea water. Also, Fig. IA, loss of ${ }^{134} \mathrm{Cs}$ by Carcinus in inactive artificial sea water. Arrows in the loss experiment show the concentration factors in animals for which tissue concentration factors are given in Table 6. 

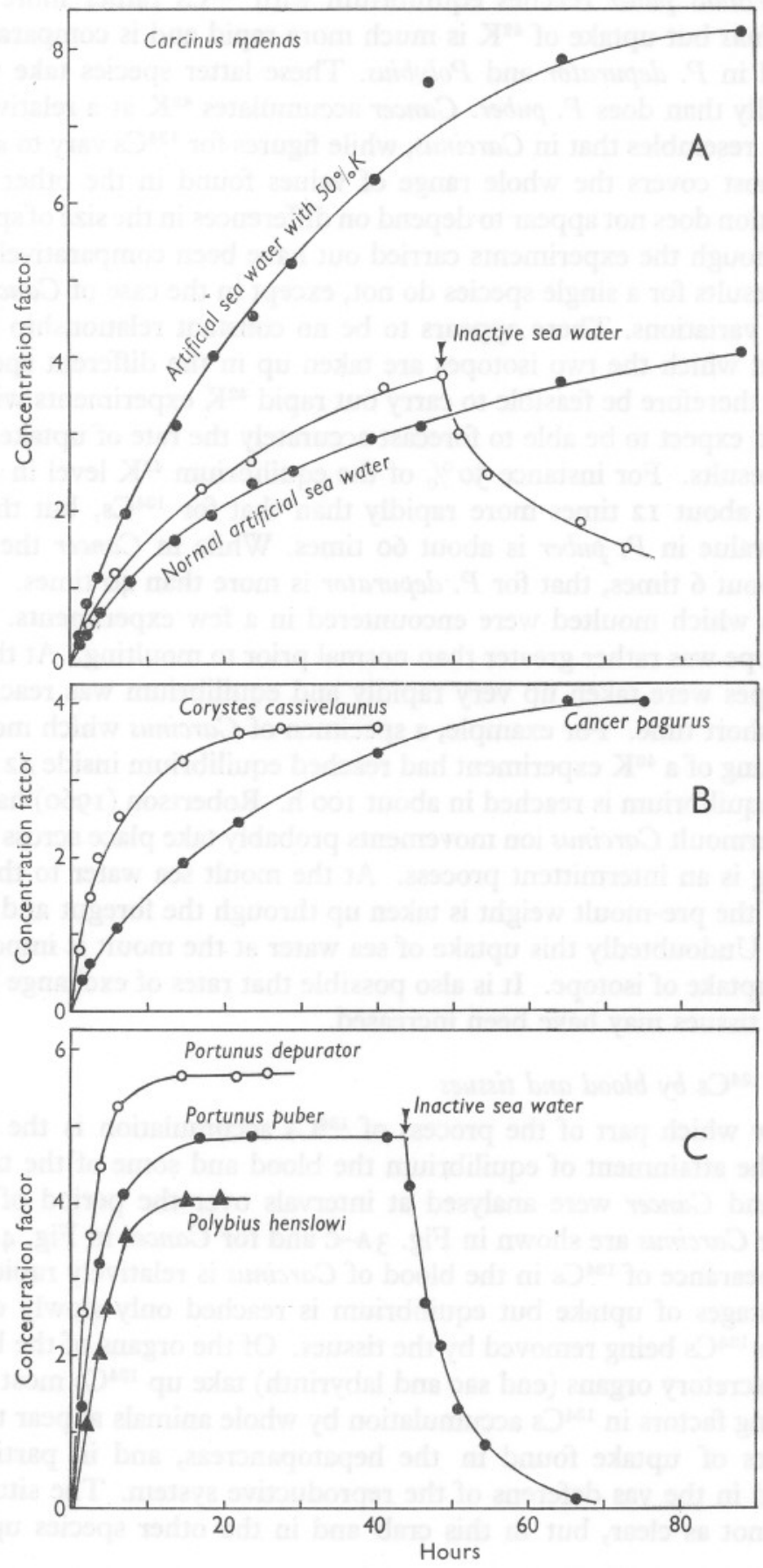

Fig. 2 A-C. Uptake of ${ }^{42} \mathrm{~K}$ by whole crabs from artificial sea water. Also, Fig. 2 A, loss of ${ }^{42} \mathrm{~K}$ by Carcinus in inactive artificial sea water. Also, Fig. $2 \mathrm{C}$, loss of ${ }^{42} \mathrm{~K}$ by Portunus puber in inactive artificial sea water. 
water. Portunus puber reaches equilibrium with ${ }^{134} \mathrm{Cs}$ rather more quickly than Carcinus but uptake of ${ }^{42} \mathrm{~K}$ is much more rapid and is comparable with that found in $P$. depurator and Polybius. These latter species take up ${ }^{134} \mathrm{Cs}$ more rapidly than does $P$. puber. Cancer accumulates ${ }^{42} \mathrm{~K}$ at a relatively slow rate which resembles that in Carcinus, while figures for ${ }^{134} \mathrm{Cs}$ vary to an extent which almost covers the whole range of values found in the other species. This variation does not appear to depend on differences in the size of specimens used. Although the experiments carried out have been comparatively few in number, results for a single species do not, except in the case of Cancer, show very wide variations. There appears to be no constant relationship between the rates at which the two isotopes are taken up in the different species. It would not therefore be feasible to carry out rapid ${ }^{42} \mathrm{~K}$ experiments with other species and expect to be able to forecast accurately the rate of uptake of ${ }^{134} \mathrm{Cs}$ from the results. For instance $50 \%$ of the equilibrium ${ }^{42} \mathrm{~K}$ level in Carcinus is reached about $\mathrm{I} 2$ times more rapidly than that for ${ }^{134} \mathrm{Cs}$, but the corresponding value in $P$. puber is about 60 times. While in Cancer the average value is about 6 times, that for $P$. depurator is more than 40 times.

Animals which moulted were encountered in a few experiments. Uptake of the isotope was rather greater than normal prior to moulting. At the moult both isotopes were taken up very rapidly and equilibrium was reached in a relatively short time. For example, a specimen of Carcinus which moulted at the beginning of a ${ }^{42} \mathrm{~K}$ experiment had reached equilibrium inside $42 \mathrm{~h}$, while normally equilibrium is reached in about $100 \mathrm{~h}$. Robertson (I960) has shown that in intermoult Carcinus ion movements probably take place across the gills as drinking is an intermittent process. At the moult sea water to the extent of $66 \%$ of the pre-moult weight is taken up through the foregut and hepatopancreas. Undoubtedly this uptake of sea water at the moult is important in the rapid uptake of isotope. It is also possible that rates of exchange between blood and tissues may have been increased.

\section{Uptake of ${ }^{134} \mathrm{Cs}$ by blood and tissues}

To show which part of the process of ${ }^{134} \mathrm{Cs}$ accumulation is the limiting factor in the attainment of equilibrium the blood and some of the tissues of Carcinus and Cancer were analysed at intervals over the period of uptake. Results for Carcinus are shown in Fig. 3A-C and for Cancer in Fig. 4A and B.

The appearance of ${ }^{134} \mathrm{Cs}$ in the blood of Carcinus is relatively rapid during the early stages of uptake but equilibrium is reached only slowly due presumably to ${ }^{134} \mathrm{Cs}$ being removed by the tissues. Of the organs of the body the gills and excretory organs (end sac and labyrinth) take up ${ }^{134} \mathrm{Cs}$ most rapidly. The limiting factors in ${ }^{134} \mathrm{Cs}$ accumulation by whole animals appear to be the slower rates of uptake found in the hepatopancreas, and in particular in muscle and in the vas deferens of the reproductive system. The situation in Cancer is not as clear, but in this crab and in the other species uptake by 

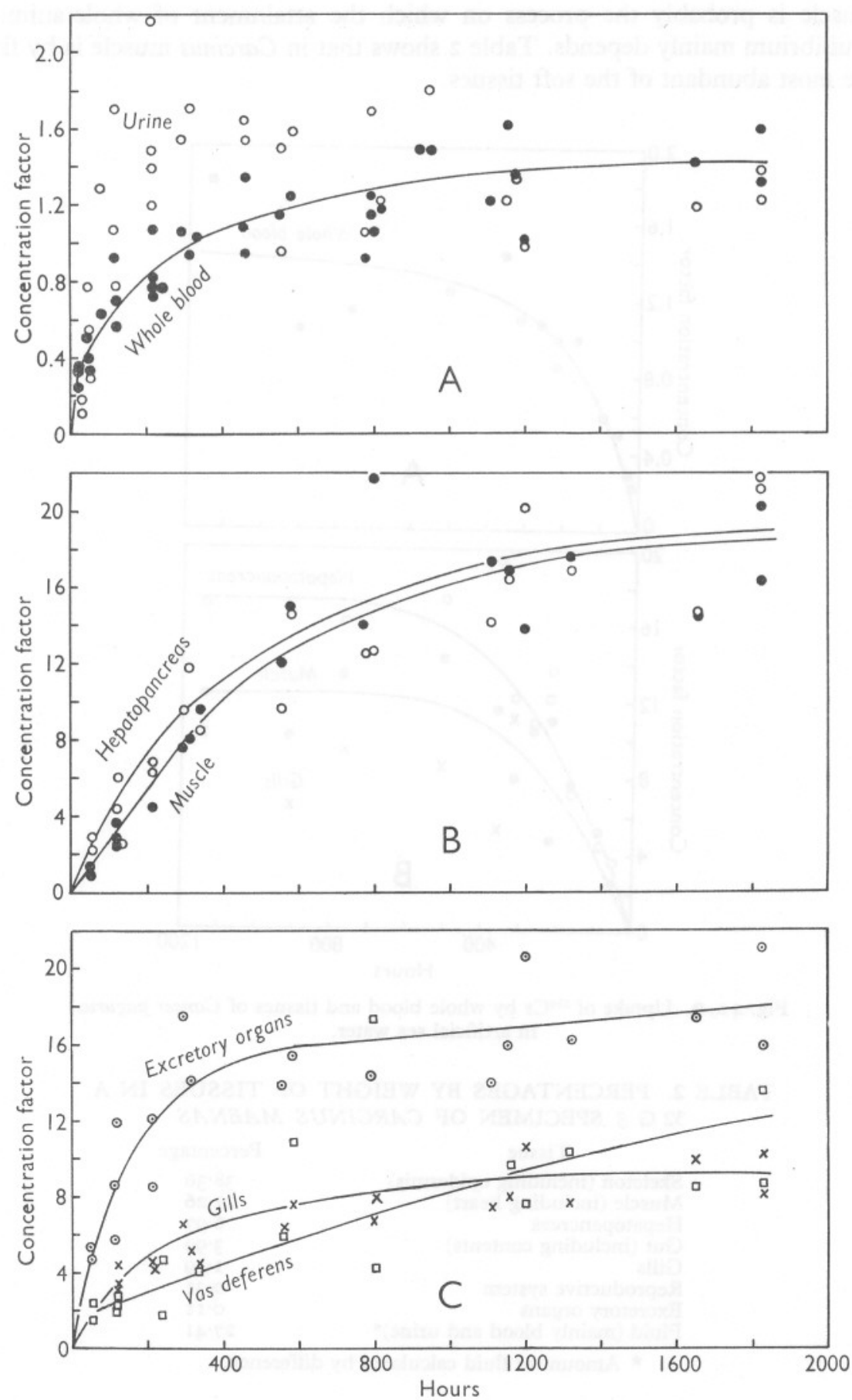

Fig. 3 A-C. Uptake of ${ }^{134} \mathrm{Cs}$ by whole blood, tissues and urine of Carcinus maenas in artificial sea water. 
muscle is probably the process on which the attainment of whole animal equilibrium mainly depends. Table 2 shows that in Carcinus muscle is by far the most abundant of the soft tissues.

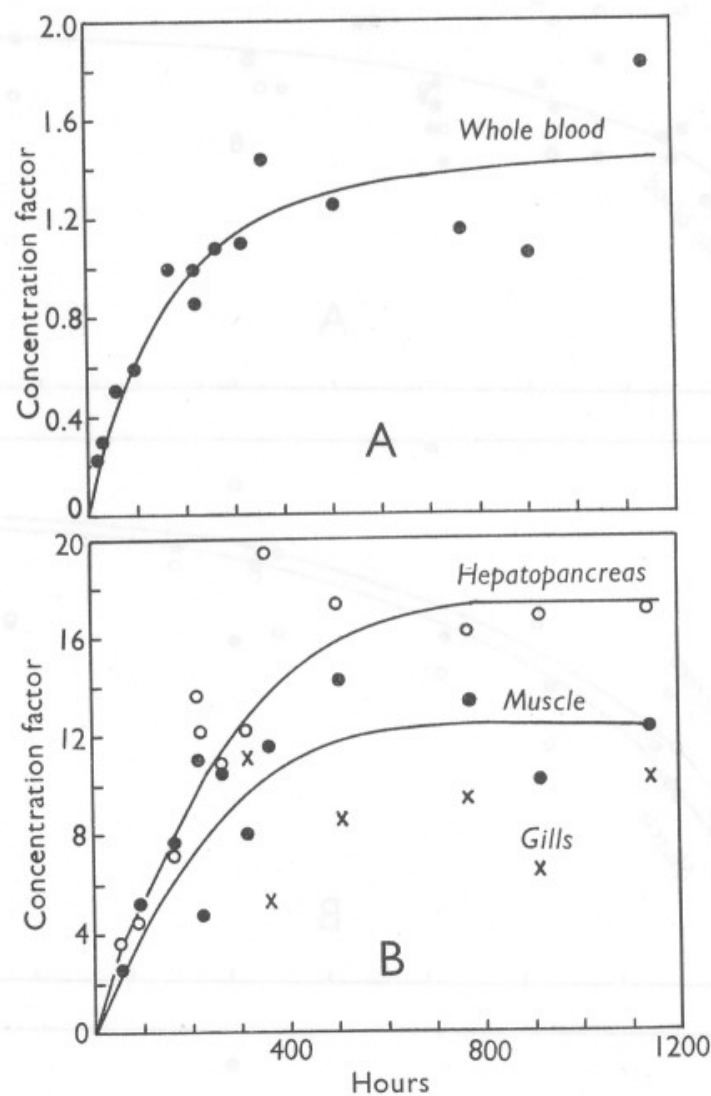

Fig. 4 A, B. Uptake of ${ }^{134} \mathrm{Cs}$ by whole blood and tissues of Cancer pagurus in artificial sea water.

TABLE 2. PERCENTAGES BY WEIGHT OF TISSUES IN A $32 \mathrm{G}$ o SPECIMEN OF CARCINUS MAENAS

Tissue

Skeleton (including epidermis)

Muscle (including heart)

Hepatopancreas

Gut (including contents)

Gills

Reproductive system

Excretory organs

Fluid (mainly blood and urine) ${ }^{\star}$
Percentage

$38 \cdot 36$

$2 \mathrm{I} \cdot 26$

6.97

3.99

I. 59

0.31

O. I I

$27 \cdot 4 \mathrm{I}$

* Amount of fluid calculated by difference. 
TABLE 3. EQUILIBRIUM CONCENTRATION FACTORS FOR ${ }^{134} \mathrm{Cs}$ AND INACTIVE K IN CRAB TISSUES

\begin{tabular}{|c|c|c|c|c|c|c|c|c|c|c|c|c|c|c|}
\hline \multirow{3}{*}{ Species } & \multirow{3}{*}{$\begin{array}{l}\text { No. of } \\
\text { animals }\end{array}$} & \multirow{3}{*}{$\begin{array}{l}\text { Mean } \\
\text { weight } \\
\text { (g) }\end{array}$} & \multirow{3}{*}{$\underset{(\mathrm{mM} / \mathrm{kg})}{\mathrm{K}}$} & \multirow{2}{*}{$\stackrel{\%}{\mathrm{H}_{2} \mathrm{O}}$} & \multicolumn{2}{|c|}{$\begin{array}{l}\text { Concentration } \\
\text { factor }\end{array}$} & \multirow{2}{*}{$\underset{(\mathrm{mM} / \mathrm{kg})}{\mathrm{K}}$} & \multirow{2}{*}{$\stackrel{\%}{\mathrm{H}_{2}} \mathrm{O}$} & \multicolumn{2}{|c|}{$\begin{array}{l}\text { Concentration } \\
\text { factor }\end{array}$} & \multirow{2}{*}{$\underset{(\mathrm{mM} / \mathrm{kg})}{\mathrm{K}}$} & \multirow{2}{*}{$\stackrel{\%}{\mathrm{H}_{2} \mathrm{O}}$} & \multicolumn{2}{|c|}{$\begin{array}{l}\text { Concentration } \\
\text { factor }\end{array}$} \\
\hline & & & & & $\mathrm{K}$ & ${ }^{134} \mathrm{Cs}$ & & & $\mathrm{K}$ & ${ }^{134} \mathrm{Cs}$ & & & $\mathrm{K}$ & ${ }^{134} \mathrm{Cs}$ \\
\hline & & & & \multicolumn{3}{|c|}{ Whole blood } & \multicolumn{4}{|c|}{ Muscle } & \multicolumn{4}{|c|}{ Hepatopancreas } \\
\hline $\begin{array}{c}\text { Carcinus } \\
\text { maenas }\end{array}$ & 5 & $36 \cdot I$ & $12 \cdot 7$ & $92 \cdot 5$ & $I \cdot 20$ & $I \cdot 43$ & 103 & $78 \cdot 2$ & $9 \cdot 8$ & $17 \cdot 7$ & 100 & $7 x \cdot 5$ & $9 \cdot 5$ & I8.7 \\
\hline $\begin{array}{l}\text { C. maenas (sea } \\
\text { water with } \\
50 \% \mathrm{~K} \text { ) }\end{array}$ & 4 & $20 \cdot 0$ & $7 \cdot I$ & - & $I \cdot 3 I$ & $I \cdot 60$ & 95 & $80 \cdot I$ & $17 \cdot 6$ & $42 \cdot 0$ & 90 & $79 \cdot 0$ & $16 \cdot 6$ & $29 \cdot 6$ \\
\hline Portunus puber & 4 & $25 \cdot 5$ & 15.5 & - & $I \cdot 44$ & $I \cdot 45$ & 102 & $80 \cdot 8$ & 9.5 & I3.I & 82 & $78 \cdot 3$ & $7 \cdot 6$ & II 9 \\
\hline$P$. depurator & I & 15.9 & $13 \cdot 2$ & - & $\mathrm{I} \cdot 34$ & $I \cdot 56$ & I08 & $78 \cdot 5$ & II $\cdot 0$ & $12 \cdot 0$ & 82 & $77 \cdot 0$ & $8 \cdot 3$ & $25 \cdot 9$ \\
\hline Cancer pagurus & 5 & $15 \cdot 2$ & $12 \cdot 3$ & - & $\mathrm{I} \cdot \mathrm{I5}$ & $I \cdot 33$ & 84 & $75 \cdot 2$ & $7 \cdot 9$ & II $\cdot 3$ & II3 & $78 \cdot 0$ & 10.6 & I9. I \\
\hline \multirow{2}{*}{$\begin{array}{l}\text { Corystes cas- } \\
\text { sivelaunus }\end{array}$} & $\mathrm{I}$ & $7 \cdot 7$ & 13.8 & - & $1 \cdot 30$ & $\mathrm{I} \cdot 26$ & II 2 & $76 \cdot 7$ & 10.6 & II $\cdot 4$ & $12 \mathrm{I}$ & $75 \cdot 0$ & II $\cdot 4$ & $24 \cdot 8$ \\
\hline & & & \multicolumn{4}{|c|}{ Gills } & \multicolumn{4}{|c|}{ Vas deferens } & \multicolumn{4}{|c|}{ Excretory organs } \\
\hline $\begin{array}{l}\text { Carcinus } \\
\text { maenas }\end{array}$ & - & - & 45 & 84.9 & $4 \cdot 3$ & $8 \cdot 2$ & I IO & $73 \cdot 7$ & 10.5 & 10.5 & 75 & $82 \cdot 5$ & $7 \cdot 2$ & $17 \cdot 5$ \\
\hline $\begin{array}{l}\text { C. maenas (sea } \\
\text { water with } \\
50 \% \mathrm{~K} \text { ) }\end{array}$ & - & - & 38 & $87 \cdot I$ & $7 \cdot 0$ & I $4 \cdot 4$ & 108 & $65 \cdot 7$ & $20 \cdot 0$ & $17 \cdot 5$ & 62 & $86 \cdot 9$ & II 5 & $22 \cdot 3$ \\
\hline Portunus puber & - & - & 46 & $87 \cdot 6$ & $4 \cdot 3$ & $8 \cdot 9$ & - & - & - & - & - & - & - & - \\
\hline $\begin{array}{l}P \text {. depurator } \\
\text { Cancer pagurus }\end{array}$ & - & - & $\begin{array}{l}31 \\
42\end{array}$ & $\begin{array}{l}86 \cdot 9 \\
87 \cdot 2\end{array}$ & $\begin{array}{l}3 \cdot I \\
3 \cdot 9\end{array}$ & $\begin{array}{l}6 \cdot 0 \\
8 \cdot 4\end{array}$ & - & - & - & - & - & - & 二 & - \\
\hline $\begin{array}{l}\text { Cancer pagurus } \\
\text { Corystes cas- }\end{array}$ & $\overline{-}$ & - & $\begin{array}{l}42 \\
52\end{array}$ & $82 \cdot 2$ & $4 \cdot 9$ & $\begin{array}{r}8 \cdot 4 \\
10 \cdot 3\end{array}$ & - & - & - & - & $\overline{-}$ & - & - & $\overline{-}$ \\
\hline
\end{tabular}


In animals where ${ }^{134} \mathrm{Cs}$ equilibrium appeared to have been reached the $\mathrm{K}$ concentrations of blood, plasma, urine and tissues were measured. The mean ${ }^{134} \mathrm{Cs}$ and $\mathrm{K}$ concentration factors for the tissues of five species are given in Table 3 together with mean values for tissue water content and $\mathrm{K}$ concentration. In nearly all cases concentration factors for ${ }^{134} \mathrm{Cs}$ exceed those for inactive $\mathrm{K}$ by a far greater margin in the tissues than in the blood. The result is that tissue/blood ratios for ${ }^{134} \mathrm{Cs}$ are nearly always greater than those for $\mathrm{K}$. Exceptions are the vas deferens of Carcinus, where equilibrium was probably not reached, and in $P$. depurator muscle where the discrepancy is small. In considering the relationship between tissue and blood concentrations it is more accurate to use the relationship tissue/plasma with concentrations calculated as per $\mathrm{kg} \mathrm{H}_{2} \mathrm{O}$. Samples of blood plasma had average ${ }^{134} \mathrm{Cs}$ and $\mathrm{K}$ concentrations about $5 \%$ lower than those of an equal weight of whole blood. Results calculated on this basis for two specimens of Carcinus after I, $824 \mathrm{~h}$, when absolute equilibrium appeared to have been reached, are given in Table 4. The implications of the higher plasma/sea water and tissue/plasma ${ }^{134} \mathrm{Cs}$ ratios will be considered in the discussion.

TABLE 4. TISSUE/PLASMA RATIOS FOR ${ }^{134} \mathrm{Cs}$ AND INACTIVE $\mathrm{K}$ IN TWO CARCINUS AFTER $1,824 \mathrm{H}$

(Ratios calculated using concentrations per $\mathrm{kg} \mathrm{H}_{2} \mathrm{O}$.)

\begin{tabular}{|c|c|c|c|c|}
\hline \multirow[b]{2}{*}{ Tissue } & \multicolumn{2}{|c|}{$\begin{array}{c}\mathrm{I} \\
(22.6 \mathrm{~g})\end{array}$} & \multicolumn{2}{|c|}{$\begin{array}{c}2 \\
(42.9 \mathrm{~g})\end{array}$} \\
\hline & $\mathrm{K}$ & ${ }^{134} \mathrm{Cs}$ & $\mathrm{K}$ & ${ }^{134} \mathrm{Cs}$ \\
\hline Muscle & $9 \cdot 8$ & I 8.7 & $8 \cdot 3$ & I2.I \\
\hline Hepatopancreas & 13.5 & $22 \cdot \mathrm{I}$ & $9 \cdot 4$ & $22 \cdot 4$ \\
\hline Gills & 4.5 & 6.9 & $4 \cdot 6$ & $7 \cdot 2$ \\
\hline Vas deferens & II $\cdot 2$ & I3.I & $12 \cdot 8$ & $7 \cdot 4$ \\
\hline Excretory organs & $8 \cdot 1$ & 20.7 & $6 \cdot 4$ & I 4.9 \\
\hline Ratio, plasma/sea water & $\mathrm{I} \cdot 07$ & $I \cdot 3 I$ & $I \cdot 53$ & $\mathrm{I} \cdot 67$ \\
\hline
\end{tabular}

\section{Loss of ${ }^{134} \mathrm{Cs}$ by Carcinus}

After accumulating ${ }^{134} \mathrm{Cs}$ for $938 \mathrm{~h}$ a specimen of Carcinus was allowed to lose activity in inactive sea water for a further $644 \mathrm{~h}$. The tissues were then analysed for ${ }^{134} \mathrm{Cs}$ and the results compared with those for an animal which had a concentration factor corresponding to the point at which loss of the isotope was commenced. A further comparison was made with an animal which had the same concentration factor but was accumulating ${ }^{134} \mathrm{Cs}$. The full course of uptake and loss is given in Fig. I A and Table 5 compares the tissue concentration factors in the three animals.

The low activities of blood, excretory organs and hepatopancreas after exposure to inactive sea water (animal 3) compared with those in animal 2 show that these tissues had lost a much larger percentage of the original ${ }^{134} \mathrm{Cs}$ than had the muscle and vas deferens. Results for animal I show that these latter tissues also accumulated ${ }^{134} \mathrm{Cs}$ most slowly. This confirms the conclusion, 
arrived at in a previous section, that muscle is the principal limiting factor in the attainment of equilibrium and also in the loss of activity. The gills were not considered in Table 5 because analyses in active sea water were carried out without washing the filaments.

Although ${ }^{134} \mathrm{Cs}$ uptake by whole Carcinus is roughly exponential a semilogarithmic plot showed that the loss of isotope is not exponential because the rate of loss is gradually decreasing. This could to some extent be a result of long starvation, but it is probably due mainly to the reabsorption by the tissues of ${ }^{134} \mathrm{Cs}$ already lost to the blood.

TABLE 5. TISSUE CONCENTRATION FACTORS FOR ${ }^{134} \mathrm{Cs}$ IN CARCINUS AT POSITIONS INDICATED BY ARROWS IN FIG. 1A

\begin{tabular}{|c|c|c|c|}
\hline & & Animal & \\
\hline & I & 2 & 3 \\
\hline Whole animal & 2.9 & $7 \cdot 2$ & 3.0 \\
\hline Whole blood & 0.93 & $I \cdot 22$ & 0.2 \\
\hline Muscle & 3.6 & $17 \cdot 3$ & $7 \cdot 9$ \\
\hline Hepatopancreas & 6.0 & $I 4 \cdot I$ & $3 \cdot 5$ \\
\hline Vas deferens & $2 \cdot 8$ & $9 \cdot 6^{\star}$ & 5.0 \\
\hline Excretory organs & II $\cdot 8$ & 13.9 & 3.5 \\
\hline
\end{tabular}

\section{Uptake of ${ }^{42} \mathrm{~K}$ by tissues}

The tissues of crabs, for which whole animal uptake curves have been given, were analysed when ${ }^{42} \mathrm{~K}$ equilibrium was reached or approached. Owing to the decay of ${ }^{42} \mathrm{~K}$ the maximum length of an experiment was about $90 \mathrm{~h}$. The standard deviation of ${ }^{42} \mathrm{~K}$ counting was $\mathrm{I}-\mathrm{I} \cdot 5 \%$ for the blood and tissues of Portunus. This was increased to about $5.5 \%$ for blood and $3 \%$ for tissues in Carcinus after $65 \mathrm{~h}$. After $90 \mathrm{~h}$ the figures were about $10 \%$ for blood and $6 \%$ for tissues. Because of this, results for animals which were analysed after about $50 \mathrm{~h}$ are fairly inaccurate. Table 6 shows the inactive $\mathrm{K}$ concentrations of blood and tissues and the levels reached by ${ }^{42} \mathrm{~K}$ are expressed as a percentage of the inactive $\mathrm{K}$ concentration factor. In both species of Portunus most of the $\mathrm{K}$ in the blood, muscle and hepatopancreas is readily exchangeable with ${ }^{42} \mathrm{~K}$. Similarly, by $90 \mathrm{~h}$ fairly complete exchange has taken place in Carcinus in normal and in $50 \% \mathrm{~K}$ artificial sea water. Equilibrium appears to have been fully reached in Cancer after $75 \mathrm{~h}$ but Corystes was probably analysed too early at $40 \mathrm{~h}$, although whole animal equilibrium appeared to have been reached.

Only in Carcinus has uptake of ${ }^{42} \mathrm{~K}$ by the individual tissues been studied in any detail. Equilibrium with ${ }^{42} \mathrm{~K}$ is substantially reached in about $\mathrm{Io} \mathrm{h}$ by the gills (Fig. 5 B). In the blood, hepatopancreas and muscle equilibrium is reached only after about $90 \mathrm{~h}$ (Figs. $5 \mathrm{~A}$ and $5 \mathrm{~B}$ ). It is not clear from the graphs whether uptake by the blood or by the tissues is the limiting process in ${ }^{42} \mathrm{~K}$ 
TABLE 6. THE PERCENTAGE EXCHANGE OF ${ }^{42} \mathrm{~K}$ FOR INACTIVE $\mathrm{K}$ IN CRAB TISSUES AT EQUILIBRIUM

(The tissue concentration factors attained by ${ }^{42} \mathrm{~K}$ are expressed as a percentage of the concentration factor for inactive $\mathrm{K}$.)

\begin{tabular}{|c|c|c|c|c|c|c|c|c|c|c|c|}
\hline \multirow[b]{2}{*}{ Species } & \multirow[b]{2}{*}{$\underset{(\mathrm{h})}{\text { Time }}$} & \multirow[b]{2}{*}{$\begin{array}{l}\text { Weight } \\
\text { (g) }\end{array}$} & \multirow[b]{2}{*}{$\begin{array}{c}\text { Sea } \\
\text { water K } \\
(\mathrm{mm} / \mathrm{kg})\end{array}$} & \multicolumn{2}{|c|}{ Whole blood } & \multicolumn{2}{|c|}{ Muscle } & \multicolumn{2}{|c|}{ Hepatopancreas } & \multicolumn{2}{|c|}{ Gills } \\
\hline & & & & $\underset{(\mathrm{mM} / \mathrm{kg})}{\mathrm{K}}$ & $\begin{array}{c}\% \\
\text { exchange } \\
\text { of }{ }^{42} \mathrm{~K}\end{array}$ & $\underset{(\mathrm{mM} / \mathrm{kg})}{\mathrm{K}}$ & $\begin{array}{c}\% \\
\text { exchange } \\
\text { of }{ }^{42} \mathrm{~K}\end{array}$ & $\underset{(\mathrm{mM} / \mathrm{kg})}{\mathrm{K}}$ & $\begin{array}{c}\% \\
\text { exchange } \\
\text { of }{ }^{42} \mathrm{~K}\end{array}$ & $\underset{(\mathrm{mM} / \mathrm{kg})}{\mathrm{K}}$ & $\begin{array}{c}\% \\
\text { exchange } \\
\text { of }{ }^{42} \mathrm{~K}\end{array}$ \\
\hline Carcinus maenas & $\begin{array}{l}65 \cdot 3 \\
89 \cdot 5\end{array}$ & $\begin{array}{l}32 \cdot 6 \\
46 \cdot 5\end{array}$ & $\begin{array}{l}\mathrm{II} \cdot 4 \\
\mathrm{II} \cdot 4\end{array}$ & $\begin{array}{l}10 \cdot 8 \\
12.9\end{array}$ & $\begin{array}{r}107 \\
95\end{array}$ & $\begin{array}{l}\text { II } 4 \\
\text { IOI }\end{array}$ & $\begin{array}{l}89 \\
94\end{array}$ & $\begin{array}{l}77 \\
65\end{array}$ & $\begin{array}{r}96 \\
100\end{array}$ & $\begin{array}{l}50 \\
47\end{array}$ & $\begin{array}{r}98 \\
105\end{array}$ \\
\hline C. maenas & $\begin{array}{l}67 \cdot 0 \\
90 \cdot 0\end{array}$ & $\begin{array}{l}23 \cdot 8 \\
29 \cdot 5\end{array}$ & $\begin{array}{l}6 \cdot 4 \\
6 \cdot 4\end{array}$ & $\begin{array}{l}9 \cdot 0 \\
8 \cdot 4\end{array}$ & $\begin{array}{l}76 \\
87\end{array}$ & $\begin{array}{l}113 \\
105\end{array}$ & $\begin{array}{l}85 \\
99\end{array}$ & $\begin{array}{l}84 \\
96\end{array}$ & $\begin{array}{l}86 \\
94\end{array}$ & $\begin{array}{l}37 \\
42\end{array}$ & $\begin{array}{r}98 \\
102\end{array}$ \\
\hline Portunus puber & $\begin{array}{l}26 \cdot I \\
26 \cdot 5\end{array}$ & $\begin{array}{l}25.5 \\
50 \cdot 1\end{array}$ & $\begin{array}{l}\mathrm{II} \cdot 2 \\
\mathrm{II} \cdot 2\end{array}$ & $\begin{array}{l}15 \cdot 2 \\
16 \cdot 4\end{array}$ & $\begin{array}{r}103 \\
98\end{array}$ & $\begin{array}{l}130 \\
131\end{array}$ & $\begin{array}{r}99 \\
104\end{array}$ & $\begin{array}{l}93 \\
96\end{array}$ & $\begin{array}{l}98 \\
86\end{array}$ & - & $=$ \\
\hline P. depurator & $\begin{array}{l}25 \cdot 5 \\
26 \cdot 8\end{array}$ & $\begin{array}{l}20 \cdot 1 \\
20 \cdot 5\end{array}$ & $\begin{array}{l}\text { II } \cdot 2 \\
\text { II } \cdot 2\end{array}$ & $\begin{array}{l}\text { I } 4 \cdot 7 \\
\text { I } 4 \cdot 4\end{array}$ & $\begin{array}{r}104 \\
95\end{array}$ & $\begin{array}{l}107 \\
132\end{array}$ & $\begin{array}{l}106 \\
100\end{array}$ & $\begin{array}{l}120 \\
105\end{array}$ & $\begin{array}{r}95 \\
105\end{array}$ & 二 & $\overline{-}$ \\
\hline Cancer pagurus & $\begin{array}{l}75 \cdot 0 \\
75 \cdot 5\end{array}$ & $\begin{array}{l}26 \cdot 4 \\
29 \cdot 0\end{array}$ & $\begin{array}{l}\text { II } \cdot 2 \\
\text { II } \cdot 2\end{array}$ & $\begin{array}{l}12 \cdot 7 \\
13 \cdot 3\end{array}$ & $\begin{array}{l}72 \\
88\end{array}$ & $\begin{array}{l}112 \\
123\end{array}$ & $\begin{array}{l}123 \\
112\end{array}$ & $\begin{array}{l}102 \\
103\end{array}$ & $\begin{array}{l}117 \\
112\end{array}$ & - & $\overline{-}$ \\
\hline $\begin{array}{l}\text { Corystes cassi- } \\
\text { velaunus }\end{array}$ & $\begin{array}{l}40 \cdot 0 \\
40 \cdot 5\end{array}$ & $\begin{array}{r}6 \cdot 8 \\
13 \cdot 5\end{array}$ & $\begin{array}{l}\text { II } \cdot 2 \\
\text { II } \cdot 2\end{array}$ & $\begin{array}{l}12 \cdot 3 \\
11 \cdot 9\end{array}$ & $\begin{array}{l}98 \\
92\end{array}$ & $\begin{array}{l}121 \\
123\end{array}$ & $\begin{array}{l}93 \\
86\end{array}$ & $\begin{array}{l}84 \\
126\end{array}$ & $\begin{array}{l}88 \\
85\end{array}$ & 二 & $\overline{-}$ \\
\hline
\end{tabular}


uptake by the whole animal. Tissue exchange is relatively rapid because by $40 \mathrm{~h}$ tissue/plasma ${ }^{42} \mathrm{~K}$ ratios have risen to values similar to those found at equilibrium although the blood has not actually attained equilibrium with the outside medium. These ratios (calculated using concentrations per $\mathrm{kg}$ wet weight as the water content was not measured) are about 9-Io for muscle and
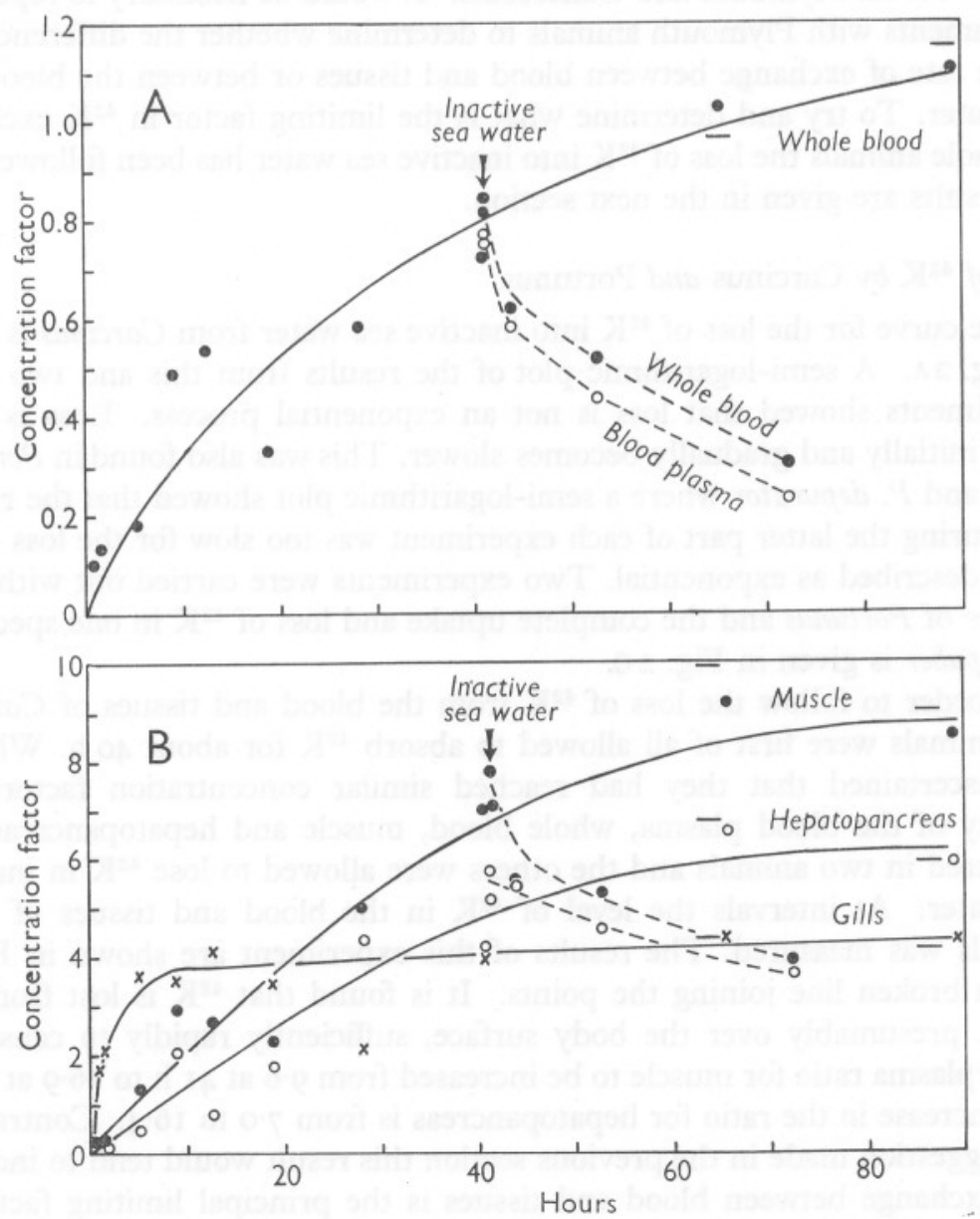

Fig. 5 A, B. Uptake and loss of ${ }^{42} \mathrm{~K}$ by whole blood, blood plasma and tissues of ${ }^{\circ}$ Carcinus maenas in artificial sea water. Short horizontal lines indicate the inactive $\mathrm{K}$ levels which were found.

between 6 and 7.5 for hepatopancreas. The fact that high tissue/plasma ratios are found well before equilibrium is reached does suggest that uptake over the body surface into the blood may in fact be the limiting process. Shaw (1958) has shown that in Carcinus injected with ${ }^{42} \mathrm{~K}$ and kept out of water, 
complete exchange with muscle $\mathrm{K}$ takes about $6 \mathrm{~h}$. When animals were immersed in sea water containing ${ }^{42} \mathrm{~K}$ he found that $48 \mathrm{~h}$ were sufficient for equilibrium to be reached between sea water and blood and between blood and muscle. In the present experiments at least $90 \mathrm{~h}$ were needed for whole animal equilibration. This is presumably a physiological difference between Carcinus from Plymouth and Cullercoats. It would be necessary to repeat his experiments with Plymouth animals to determine whether the difference was in the rate of exchange between blood and tissues or between the blood and sea water. To try and determine what is the limiting factor in ${ }^{42} \mathrm{~K}$ exchange by whole animals the loss of ${ }^{42} \mathrm{~K}$ into inactive sea water has been followed and the results are given in the next section.

\section{Loss of ${ }^{42} \mathrm{~K}$ by Carcinus and Portunus}

One curve for the loss of ${ }^{42} \mathrm{~K}$ into inactive sea water from Carcinus is given in Fig. 2A. A semi-logarithmic plot of the results from this and two other experiments showed that loss is not an exponential process. Loss is most rapid initially and gradually becomes slower. This was also found in Portunus puber and $P$. depurator where a semi-logarithmic plot showed that the rate of loss during the latter part of each experiment was too slow for the loss curve to be described as exponential. Two experiments were carried out with each species of Portunus and the complete uptake and loss of ${ }^{42} \mathrm{~K}$ in one specimen of $P$. puber is given in Fig. $2 \mathrm{C}$.

In order to follow the loss of ${ }^{42} \mathrm{~K}$ from the blood and tissues of Carcinus five animals were first of all allowed to absorb ${ }^{42} \mathrm{~K}$ for about $40 \mathrm{~h}$. When it was ascertained that they had reached similar concentration factors the activity of the blood plasma, whole blood, muscle and hepatopancreas was measured in two animals and the others were allowed to lose ${ }^{42} \mathrm{~K}$ in inactive sea water. At intervals the level of ${ }^{42} \mathrm{~K}$ in the blood and tissues of these animals was measured. The results of this experiment are shown in Fig. 5 with a broken line joining the points. It is found that ${ }^{42} \mathrm{~K}$ is lost from the blood, presumably over the body surface, sufficiently rapidly to cause the tissue/plasma ratio for muscle to be increased from $9 \cdot 6$ at $4 \mathrm{I} \mathrm{h}$ to 16.9 at $72 \mathrm{~h}$. The increase in the ratio for hepatopancreas is from $7 \cdot 0$ to 16.4 . Contrary to the suggestion made in the previous section this result would tend to indicate that exchange between blood and tissues is the principal limiting factor in ${ }^{42} \mathrm{~K}$ exchange between the whole crab and sea water. It is therefore likely that the time constants governing the uptake of ${ }^{42} \mathrm{~K}$ by the blood from sea water and by the hepatopancreas and muscle from the blood are sufficiently alike for all three to be limiting factors in the attainment of equilibrium by the whole animal. 


\section{Feeding and ${ }^{134} \mathrm{Cs}$ uptake in Carcinus}

Feeding might have the metabolic effect of causing an increase in the rates of processes responsible for ${ }^{134} \mathrm{Cs}$ accumulation. Stobbart (I959) has shown that in the larvae of the mosquito Aëdes aegypti ${ }^{22} \mathrm{Na}$ is absorbed far more rapidly in fed than starved animals. In radioactive sea water feeding on inactive food might enhance uptake as a result of the absorption of isotope from fluid taken in with the food. Feeding on active food would definitely be expected to increase the rate and extent of isotope accumulation.

An example of ${ }^{134} \mathrm{Cs}$ uptake by Carcinus fed on inactive food in active artificial sea water is given in Fig. I A where it is compared with two starved animals. This $36 \mathrm{~g}$ crab was given as much food as it could eat before the experiment and given a total of $\mathrm{I} 2 \mathrm{~g}$ of Nereis diversicolor at eight intervals over the first $1000 \mathrm{~h}$ of ${ }^{134} \mathrm{Cs}$ uptake. Two of these experiments were carried out and uptake curves for these and for starved animals were so similar that up to I000 h starvation appears to have no effect. It can be seen in Fig. I A that the concentration factor for the starved animal falls slightly at equilibrium. This is probably due to the decreasing size of the hepatopancreas and would not be expected to be found in fed animals.

The accumulation of ${ }^{134} \mathrm{Cs}$ from food and its subsequent loss in inactive sea water has also been studied. Crabs weighing between 5 and $10 \mathrm{~g}$, which had been starved for from 3 days to 2 weeks, were fed in inactive sea water on an excess of radioactive Nereis diversicolor. The Nereis had a mean concentration factor of 5.8 in sea water containing $5 \mu \mathrm{C} / 1$. of ${ }^{134} \mathrm{Cs}$. This is approximately the concentration factor found at equilibrium. The activity of a fed crab was measured with the animal held $5 \mathrm{~cm}$ below the end window of a $\gamma$-scintillation counter. Crabs consumed most of the food in the first hour and after $2 \mathrm{~h}$ feeding was virtually completed. The amount of Nereis eaten by each animal was equal, in most cases, to between 8 and $9 \%$ of the body weight of the starved crab. This figure probably represents the maximum capacity of the crab foregut. The crabs were allowed to lose ${ }^{134} \mathrm{Cs}$ in inactive sea water and then at intervals the activities of blood, muscle, hepatopancreas and the whole of the gut were measured on wet ashed samples from different individuals. Tissue activities were corrected for the fact that the initial activity per gram of whole animal was not exactly the same in each crab.

Results in Fig. $6 \mathrm{~A}$ correspond to those for an animal of $9.4 \mathrm{~g}$ which consumed $0.68 \mathrm{~g}$ of Nereis with an activity of $29 \mu \mathrm{C} / \mathrm{g}$. In actual fact Fig. $6 \mathrm{~B}$ shows that the animals which were analysed had lost ${ }^{134} \mathrm{Cs}$ at rather different rates but this was not taken into account. Rapid digestion and absorption of the food over the first $24 \mathrm{~h}$ causes the activity of blood, hepatopancreas and muscle to rise while that of the foregut falls as it empties. The fall in the activity of the whole animal is probably due to losses over the body surface and by excretion rather than to losses in the faeces. Most of the faeces were 
produced over the first $48 \mathrm{~h}$ after feeding and their activity was low although leaching out had probably taken place. As was found in previous experiments on the loss of ${ }^{134} \mathrm{Cs}$, the isotope was lost rapidly from the blood and more rapidly from the hepatopancreas than from muscle. By giving some animals a second radioactive meal after $100 \mathrm{~h}$ a marked stepwise increase in the activity of the tissues was produced. By feeding in a contaminated environment Carcinus would be expected to shorten the time taken to reach equilibrium with the sea water and also to enhance the level eventually reached.
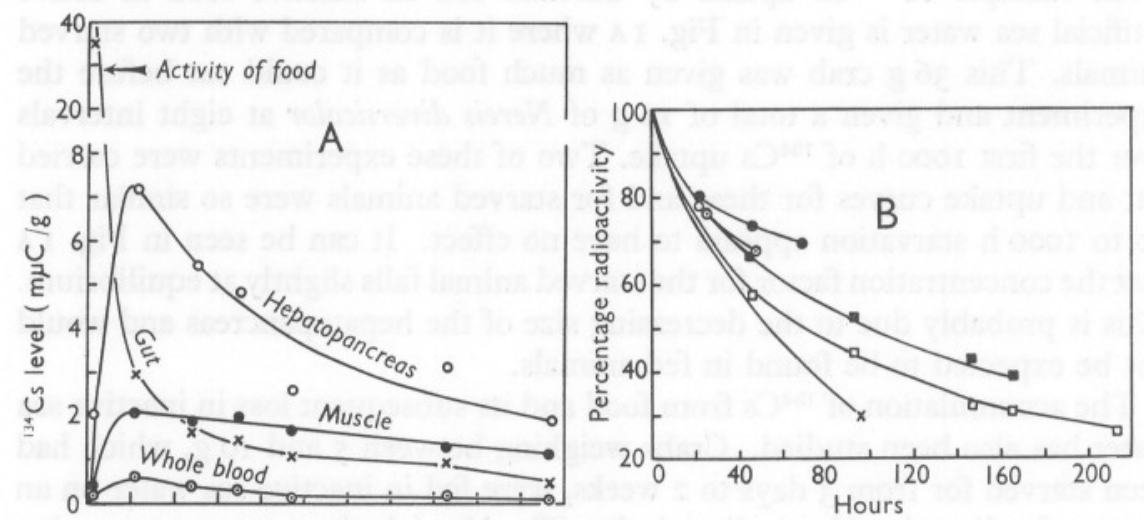

Fig. $6 \mathrm{~A}$. Changes in the ${ }^{134} \mathrm{Cs}$ activity of Carcinus blood and tissues following a single meal of radioactive Nereis diversicolor in inactive sea water. The results are for an animal of $9.4 \mathrm{~g}$ which ate $0.68 \mathrm{~g}$ of Nereis. Lower scale represents hours, as in B.

Fig. $6 \mathrm{~B}$. Loss of ${ }^{134} \mathrm{Cs}$ in inactive sea water by six Carcinus the tissues of which were used for the analyses in Fig. $6 \mathrm{~A}$.

\section{Excretion of ${ }^{134} \mathrm{Cs}$ and $\mathrm{K}$}

In Carcinus the level of ${ }^{134} \mathrm{Cs}$ in the urine has been measured in animals exposed to the isotope for different lengths of time. These results, for one excretory organ only, are shown as concentration factors in Fig. 3A. In many cases the levels of ${ }^{134} \mathrm{Cs}$ in urine after $200 \mathrm{~h}$ are as high as or higher than values found when the blood activity had further increased and equilibrium had been reached. To check that this was not a result of individual variation, simultaneous plasma and urine samples were taken from the same individuals over a period of up to $1200 \mathrm{~h}$. Blood samples of about $0.02 \mathrm{ml}$. were taken from the region between the carapace and rear walking leg with a fine syringe with the result that very little blood escaped from the animal. The blood was centrifuged and the plasma sample weighed and dried on a planchet before counting. Fig. 7 shows the corresponding blood and urine ${ }^{134} \mathrm{Cs}$ concentrations relative to sea water calculated as per $\mathrm{kg} \mathrm{H}_{2} \mathrm{O}$ which were found during uptake in three animals. 
In each case the urine activity at about $200 \mathrm{~h}$ is two or more times that of the blood while after $800 \mathrm{~h}$ it has fallen to a level only slightly greater than that of the blood. It was thought that this rather odd result might be due to the long period of starvation endured by these animals. One of the animals was fed three times on as much inactive Nereis diversicolor as it could consume but the rise in activity of the urine which resulted was very small. Two more shorter experiments were carried out in which the animals were fed. In both cases the activity of the urine fell relative to that of the blood during uptake.

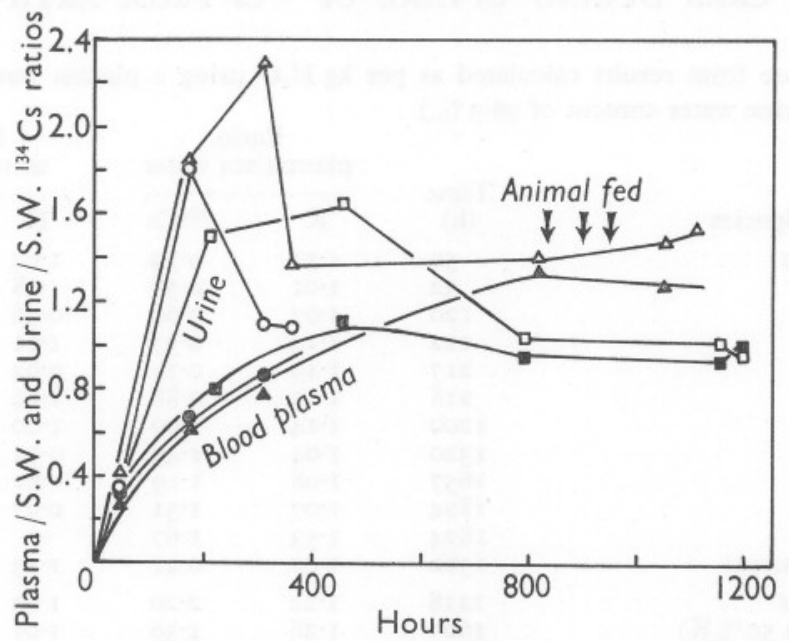

Fig. 7. Corresponding plasma/sea water and urine/sea water ${ }^{134} \mathrm{Cs}$ ratios (from concentrations calculated as per $\mathrm{kg} \mathrm{H}_{2} \mathrm{O}$ ) measured during the uptake of ${ }^{134} \mathrm{Cs}$ by three Carcinus from artificial sea water.

No connexion could be found between these changes in urine activity and in the total activity of the excretory organ which increased gradually up to equilibrium (Fig. 3C).

Results for Carcinus in which both ${ }^{134} \mathrm{Cs}$ and $\mathrm{K}$ levels of plasma and urine were measured are shown in Table 7. These figures show how the urine/ plasma ratio changes during uptake. In the initial stages of uptake the urine activity may be less than that of the blood due to its being diluted by inactive urine present at the start of uptake. The urine activity then rises until it is about twice that of the blood. Later the urine activity falls to a level similar or sometimes less than that of the blood. During these changes urine/plasma ratios for $\mathrm{K}$ remain constant at about $\mathrm{I} \cdot \mathrm{O}$. After $\mathrm{I}, 200 \mathrm{~h}$ the plasma/sea water ratios for ${ }^{134} \mathrm{Cs}$ exceed those for $\mathrm{K}$ and both values are greater than $\mathrm{I} \cdot 0$. In animals which had reached equilibrium in artificial sea water with $50 \% \mathrm{~K}$ the results are generally similar but the plasma/sea water ratios for both ions are on average rather higher.

Measurements which were made in $P$. puber and Cancer at equilibrium are 
also shown in Table 7. In Portunus the mean urine/plasma ratio for $\mathrm{K}$ was 0.77 and a value of 0.89 was found in Cancer. The corresponding values for ${ }^{134} \mathrm{Cs}$ in both animals were markedly greater and in four out of five cases exceeded $\mathrm{I} \cdot \mathrm{O}$. Where urine samples were taken during the earlier stages of uptake in Portunus, higher urine/plasma ratios were found which indicates a similarity to Carcinus that may exist in the other species as well.

TABLE 7. LEVELS OF ${ }^{134} \mathrm{Cs}$ AND $\mathrm{K}$ IN PLASMA AND URINE OF THREE SPECIES OF CRAB DURING UPTAKE OF ${ }^{134} \mathrm{CS}$ FROM ARTIFICIAL SEA WATER

(The ratios are from results calculated as per $\mathrm{kg} \mathrm{H}_{2} \mathrm{O}$ using a plasma water content of $92.5 \%$ and a urine water content of $96.3 \%$.)

\begin{tabular}{|c|c|c|c|c|c|}
\hline \multirow[b]{2}{*}{ Species } & \multirow{2}{*}{$\underset{(\mathrm{h})}{\mathrm{Time}}$} & \multicolumn{2}{|c|}{$\begin{array}{c}\text { Ratio, } \\
\text { plasma/sea water }\end{array}$} & \multicolumn{2}{|c|}{$\begin{array}{l}\text { Ratio, } \\
\text { urine/plasma }\end{array}$} \\
\hline & & $\mathrm{K}$ & ${ }^{134} \mathrm{Cs}$ & $\mathrm{K}$ & ${ }^{134} \mathrm{Cs}$ \\
\hline Carcinus maenas & $\begin{array}{r}50 \\
52 \\
120 \\
122 \\
217 \\
218 \\
1200 \\
1320 \\
1657 \\
1824 \\
1824 \\
1582\end{array}$ & $\begin{array}{l}I \cdot 3 I \\
I \cdot 0 I \\
I \cdot 07 \\
I \cdot I 4 \\
I \cdot I 9 \\
I \cdot I 3 \\
I \cdot I 4 \\
I \cdot 04 \\
I \cdot 08 \\
I \cdot 07 \\
I \cdot 53 \\
I \cdot 02\end{array}$ & $\begin{array}{l}0.39 \\
0.38 \\
0.60 \\
0.57 \\
0.74 \\
0.88 \\
1.00 \\
1.45 \\
1 \cdot 19 \\
1 \cdot 31 \\
1.67 \\
0.21\end{array}$ & $\begin{array}{l}\mathrm{I} \cdot 04 \\
\mathrm{I} \cdot 08 \\
0.96 \\
\mathrm{I} \cdot 01 \\
0.94 \\
\mathrm{I} \cdot 02 \\
\mathrm{I} \cdot 00 \\
0.94 \\
0.82 \\
0.97 \\
1 \cdot 13\end{array}$ & $\begin{array}{l}0.82 \\
I \cdot 45 \\
I \cdot 3 I \\
I \cdot 90 \\
I .89 \\
2.48 \\
0.95 \\
I \cdot 20 \\
I \cdot 01 \\
I .06 \\
0.63 \\
0.53\end{array}$ \\
\hline $\begin{array}{l}\text { Carcinus maenas } \\
\text { (Sea water with } 50 \% \mathrm{~K} \text { ) }\end{array}$ & $\begin{array}{l}1218 \\
1607 \\
1747 \\
1748\end{array}$ & $\begin{array}{l}I \cdot 22 \\
I \cdot 28 \\
I \cdot 52 \\
I \cdot 24\end{array}$ & $\begin{array}{l}2 \cdot 20 \\
I \cdot 36 \\
I \cdot 4 I \\
I \cdot 40\end{array}$ & $\begin{array}{l}I \cdot 03 \\
I \cdot 0 I \\
O \cdot 83 \\
I \cdot I 3\end{array}$ & $\begin{array}{l}0.85 \\
1.00 \\
0.85 \\
0.85\end{array}$ \\
\hline Portunus puber & $\begin{array}{r}957 \\
980 \\
\text { I } 129\end{array}$ & $\begin{array}{l}I \cdot 39 \\
I \cdot 62 \\
I \cdot 32\end{array}$ & $\begin{array}{l}I \cdot 29 \\
2 \cdot 06 \\
I \cdot 20\end{array}$ & $\begin{array}{l}0.76 \\
0.71 \\
0.85\end{array}$ & $\begin{array}{l}I \cdot 27 \\
0 \cdot 82 \\
I \cdot 2 I\end{array}$ \\
\hline Cancer pagurus & $\begin{array}{l}766 \\
911\end{array}$ & $\begin{array}{l}I \cdot I 4 \\
I \cdot 2 I\end{array}$ & $\begin{array}{l}I \cdot I 5 \\
I \cdot 05\end{array}$ & $\begin{array}{l}0.98 \\
0.8 I\end{array}$ & $\begin{array}{l}I \cdot 55 \\
I \cdot 22\end{array}$ \\
\hline
\end{tabular}

\section{DISCUSSION}

In the family Portunidae the species in order of the decreasing rate of accumulation of ${ }^{134} \mathrm{Cs}$ by whole animals are Polybius $>$ P. depurator $>P$. puber $>$ Carcinus. This is the order which might be expected when the habitat of each animal is considered. The rather transparent swimming crab Polybius would be expected to be more permeable than $P$. depurator, which would in turn be expected to be more permeable than the shore-living $P$. puber and the euryhaline Carcinus. However, the first three species take up ${ }^{42} \mathrm{~K}$ at a very similar rate, separating them from Carcinus where uptake is very much slower. Corystes takes up ${ }^{42} \mathrm{~K}$ much more rapidly than Cancer, yet in the one experiment which was carried out it accumulated ${ }^{134} \mathrm{Cs}$ at least as slowly. As has already been pointed out, the lack of any close relationship between the rates 
at which the two ions are taken up in the different species would make it impossible to predict with any accuracy the rates of uptake of ${ }^{134} \mathrm{Cs}$ in other species on the basis of experiments with ${ }^{42} \mathrm{~K}$.

Most, if not all, of the $\mathrm{K}$ in these crabs is readily exchangeable with ${ }^{42} \mathrm{~K}$. Although ${ }^{134} \mathrm{Cs}$ is accumulated much more slowly than ${ }^{42} \mathrm{~K}$ by whole animals the concentration factors reached at equilibrium are higher. The penetration of ${ }^{134} \mathrm{Cs}$ into the blood is much slower than the penetration of ${ }^{42} \mathrm{~K}$, and at equilibrium the concentration factor reached is rather greater than that for $\mathrm{K}$ while both exceed $\mathrm{I} \cdot 0$. These ions presumably enter the blood via the cells of the gills. At equilibrium the concentration factor for ${ }^{134} \mathrm{Cs}$ in the gills is about twice that for $\mathrm{K}$. The higher concentration factors for ${ }^{134} \mathrm{Cs}$ in gills and blood must represent differences between the relative rates of uptake and loss of ${ }^{134} \mathrm{Cs}$ and $\mathrm{K}$ at the inner and outer borders of the gill cells. Webb (I940) showed that in Carcinus the blood $\mathrm{K}$ level was rather greater than that of the outside medium which indicated that some active transport of $\mathrm{K}$ must have taken place between the sea water and the blood. With ${ }^{134} \mathrm{Cs}$ a proportionally greater amount of active uptake must have taken place, particularly as relatively more ${ }^{134} \mathrm{Cs}$ than $\mathrm{K}$ is usually removed in the urine. However, active movements of both ${ }^{134} \mathrm{Cs}$ and ${ }^{42} \mathrm{~K}$ are probably relatively unimportant compared with penetration of the isotopes into the blood by diffusion and exchange diffusion. No attempt has been made to measure the proportion of ${ }^{134} \mathrm{Cs}$ which penetrates by these different means. All tissues take up ${ }^{134} \mathrm{Cs}$ far more slowly than ${ }^{42} \mathrm{~K}$ but the ${ }^{134} \mathrm{Cs}$ concentration factors at equilibrium exceed those for K. In Carcinus, tissues took up and lost ${ }^{134} \mathrm{Cs}$ in order of decreasing rate: excretory organ $>$ hepatopancreas $>$ muscle $>$ vas deferens. This was probably also true of the other crabs. It appears to be a fairly general rule that muscle takes up radioactive Cs more slowly than the majority of soft tissues. For instance the scallop Pecten irradians showed a slower uptake of ${ }^{137} \mathrm{Cs}$ by muscle than other soft tissues and a higher activity was eventually reached (Chipman, 1960).

Mullins (1959, I960) has attempted to explain why $\mathrm{Rb}, \mathrm{Cs}$ and $\mathrm{Na}$ penetrate passively into frog sartorius muscle more slowly than $\mathrm{K}$ in terms of differences in the crystal radii of these ions. He suggests that the permeability of the muscle membrane to a given ion depends on the number of pores in the membrane which are of an appropriate size. Changes in the relative permeability of the membrane to different ions would indicate that the relative numbers of appropriate pores had changed. In support of this theory Mullins \& Moore (I960) measured the fluxes of univalent thallous ions across the muscle membrane. These ions have a crystal radius which lies between those of $\mathrm{K}$ and $\mathrm{Rb}$. The results suggested that the fibre membrane was unable to distinguish between $\mathrm{K}$ and $\mathrm{Tl}$, in that similar fluxes were found for the two ions and at equilibrium $\mathrm{Tl}$ was distributed across the membrane according to a Donnan ratio similar to that for $\mathrm{K}$. The distribution of $\mathrm{K}$ across the fibre 
membrane in frog sartorius appears to be adequately explained by the theory put forward by Boyle \& Conway (I94I) (Conway, I960). In its simplest form the theory supposes that a Donnan equilibrium is set up across the fibre membrane as a result of the presence of negatively charged non-diffusible material inside the cell and a high external $\mathrm{Na}$ concentration. Normally the permeability of the membrane to $\mathrm{Na}$ is lower than that to $\mathrm{K}$ and $\mathrm{Cl}$ ions which are assumed to move passively and any leakage of $\mathrm{Na}$ into the cell is corrected by active extrusion. This theory is supported by the fact that measurements of the actual fibre membrane potential are similar to the calculated potential difference required to maintain the observed $\mathrm{K}$ distribution passively. In Carcinus muscle Shaw (1958) compared the observed and calculated potential differences across muscle fibres and concluded that for the most part $\mathrm{K}$ distribution was passive. It has been shown that in Carcinus and other crabs tracer amounts of ${ }^{134} \mathrm{Cs}$ are distributed between tissues and blood at equilibrium in such a way that tissue/plasma ratios may be double those for $\mathrm{K}$. If ${ }^{134} \mathrm{Cs}$ were also passively distributed in Carcinus muscle then regardless of the time taken to reach equilibrium the final ${ }^{134} \mathrm{Cs}$ muscle/plasma ratio would be expected to equal that for $\mathrm{K}$ but not exceed it. Relman et al. (I957) have discussed ways in which higher tissue/plasma values for $\mathrm{Cs}$ than $\mathrm{K}$ could be achieved in rats fed on equal amounts of these ions. The two general alternative explanations are to suppose that active transport is in some way responsible or to explain results in terms of selective adsorption within the cell. An example of the former explanation would be to suppose that in crab tissues there is a small proportion of active $\mathrm{K}$ uptake. The same carrier although probably having a smaller affinity for $\mathrm{Cs}$ than $\mathrm{K}$ would be responsible for some ${ }^{134} \mathrm{Cs}$ uptake. If passive uptake of ${ }^{134} \mathrm{Cs}$ was sufficiently slow then the active component could still constitute a greater percentage of the total influx than in the case of $\mathrm{K}$. Provided losses were correspondingly slow a ${ }^{134} \mathrm{Cs}$ tissue/plasma ratio greater than that for $\mathrm{K}$ could be achieved. An alternative theory is that of Ling which bases the selective accumulation of $\mathrm{K}$ by cells on cation binding at fixed negative charges within the cell. The relatively higher internal level of ${ }^{134} \mathrm{Cs}$ would be explained in terms of preferential binding. The most recent evidence for this 'Fixed Charge-Induction Hypothesis' is given by Ling (I960).

Webb (I940) analysed the urine of Carcinus and concluded that $\mathrm{Mg}$ and $\mathrm{SO}_{4}$ were selectively removed from the animal while $\mathrm{K}$ was retained. The urine/ plasma ratios for $\mathrm{Mg}$ and $\mathrm{SO}_{4}$ were respectively about 3.9 and $2 \cdot 2$. In order to obtain such ratios it must be assumed that either water has been reabsorbed from a urine produced initially by filtration of the blood or that these ions are secreted either in full or in addition to those in the filtered urine. A urine/ plasma ratio of about $\mathrm{I} \cdot \mathrm{O}$ for inulin in the lobster Homarus americanus found by Burger (1957) under similar conditions indicates that water reabsorption is possibly not important and that these ions are secreted to a large extent. 
The urine/plasma ratio for $\mathrm{K}$ found by Webb was about $0 \cdot 78$, indicating that if urine is produced initially by filtration then some $\mathrm{K}$ had been reabsorbed. In the present work the urine/plasma $\mathrm{K}$ ratio found in Carcinus was about $\mathrm{I} \cdot 0$, indicating neither reabsorption nor secretion but ratios as high as 2.48 were obtained for ${ }^{134} \mathrm{Cs}$ which are presumably the result of some secretion. Under circumstances where equilibrium was approached, this ratio for ${ }^{134} \mathrm{Cs}$ fell to about $\mathrm{I} \cdot \mathrm{O}$ and in some cases to a lower level which suggested reabsorption. The reason for the fall in ${ }^{134} \mathrm{Cs}$ urine/plasma ratios as equilibrium was approached did not appear to be a result of long starvation and no other satisfactory explanation has been found. It is possible that after the period required to attain equilibrium the animal in some way becomes adapted to $\mathrm{Cs}$ ions and ceases to excrete them preferentially.

Robertson (I939) showed that in Cancer the urine/plasma ratio for K was $0.8 \mathrm{I}$. In the present work a mean value of 0.89 was found while that for ${ }^{134} \mathrm{Cs}$ at equilibrium was $\mathrm{I} \cdot 38$. This suggests that $\mathrm{K}$ may be reabsorbed from primary filtered urine while ${ }^{134} \mathrm{Cs}$ is secreted into it. Similarly, in $P$. puber the mean urine/plasma ratio for $\mathrm{K}$ was 0.77 while that for ${ }^{134} \mathrm{Cs}$ at equilibrium was $\mathrm{I} \cdot \mathrm{I}$. As in Carcinus the cells of the excretory organs of Cancer and P. puber have higher tissue/plasma ratios for ${ }^{134} \mathrm{Cs}$ than $\mathrm{K}$. When a urine/plasma ratio of $\mathrm{I} \cdot 0$ is found for $\mathrm{K}$ or ${ }^{134} \mathrm{Cs}$ then presumably excretory cells in contact with both blood and urine are maintaining similar equilibria across both cell walls. Whether the cells absorb or secrete $\mathrm{K}$ or ${ }^{134} \mathrm{Cs}$ giving urine/plasma ratios less than $\mathrm{I} \cdot \mathrm{O}$ will probably depend on the two walls of the excretory cells behaving differently from each other. The cells lining the proximal tubules of Necturus kidney have definitely been shown to be asymmetric (Whittembury, I960) and this may also be the case in crabs.

A feature of ${ }^{134} \mathrm{Cs}$ absorption from food was the rapidity and completeness with which it took place. It has not definitely been shown which part of the gut is responsible for the absorption of ions but the rapid increase in the activity of the hepatopancreas after a meal suggests that it may be the main site of ${ }^{134} \mathrm{Cs}$ uptake. The isotope probably reaches the blood and then the other tissues by some absorption through the walls of the rest of the gut as well.

I should like to thank Mr L. G. Hummerstone for his help with this work which was supported by the United Kingdom Atomic Energy Authority.

\section{SUMMARY}

The accumulation of ${ }^{134} \mathrm{Cs}$ and ${ }^{42} \mathrm{~K}$ from artificial sea water has been followed in crabs of the following species, viz. Carcinus maenas, Portunus puber, $P$. depurator, Polybius henslowi, Cancer pagurus and Corystes cassivelaunus. In all cases ${ }^{134} \mathrm{Cs}$ is taken up far more slowly than ${ }^{42} \mathrm{~K}$ but at equilibrium a 
higher concentration factor is attained by ${ }^{134} \mathrm{Cs}$. In Carcinus a value of about 8 is found for ${ }^{134} \mathrm{Cs}$ and about 4 for ${ }^{42} \mathrm{~K}$. Uptake of ${ }^{134} \mathrm{Cs}$ in Carcinus is not affected by feeding on inactive food over a period of $1000 \mathrm{~h}$. The relationship between the rates of uptake of the two isotopes is not the same in the different species and it is concluded that it would not be possible to predict with any accuracy rates of uptake for ${ }^{134} \mathrm{Cs}$ in other species of crabs from the results of short ${ }^{42} \mathrm{~K}$ experiments.

Uptake of ${ }^{134} \mathrm{Cs}$ was followed in the blood and tissues of Carcinus and Cancer, and muscle is the principal limiting factor in the attainment of equilibrium by whole animals. Uptake of ${ }^{42} \mathrm{~K}$ by tissues has also been followed and in all species nearly all the inactive $\mathrm{K}$ appears to be readily exchangeable. At equilibrium in all species plasma/sea water and tissue/plasma ${ }^{134} \mathrm{Cs}$ ratios nearly always exceed those for inactive $\mathrm{K}$. The tissue/plasma ${ }^{134} \mathrm{Cs}$ ratios in Carcinus are about twice those for $\mathrm{K}$ and the significance of this has been discussed.

Loss of both isotopes in whole Carcinus is a slower process than uptake. Isotope accumulation takes place mainly across the body surface in unfed animals, but uptake of ${ }^{134} \mathrm{Cs}$ from food is very rapid and complete and would considerably enhance the attainment of equilibrium in a natural environment.

Selective excretion of ${ }^{134} \mathrm{Cs}$ relative to $\mathrm{K}$ has been found in Carcinus, Cancer and Portunus puber.

\section{REFERENCES}

BARNES, H., I954. Some tables for the ionic composition of sea water. F. exp. Biol., Vol. 31, pp. 582-88.

Boyle, P. J. \& Conway, E. J., I94I. Potassium accumulation in muscle and associated changes. F. Physiol., Vol. roo, pp. I-63.

BURger, J. W., I957. The general form of excretion in the lobster Homarus. Biol. Bull., Woods Hole, Vol. I13, pp. 207-23.

Chipman, W. A., I960. Biological aspects of disposal of radioactive wastes into marine environments. In Disposal of Radioactive Wastes. Vienna: International Atomic Energy Agency.

Conway, E. J., I960. Principles underlying the exchanges of $\mathrm{K}$ and $\mathrm{Na}$ across cell membranes. F. gen. Physiol., Vol. 43, Supplement I, pp. I7-4I.

FRETTER, V., 1955. Uptake of radioactive sodium $\left({ }^{24} \mathrm{Na}\right)$ by Nereis diversicolor Mueller and Perinereis cultrifera (Grube). F. mar. biol. Ass. U.K., Vol. 34, pp. 151-60.

IsHIBASHI, M. \& HARA, T., 1959. On the amount of cesium dissolved in sea water. Bull. Inst. chem. Res., Kyoto Univ., Vol. 37, pp. 179-84.

LING, G. N., I960. The interpretation of selective ionic permeability and cellular potentials in terms of the fixed charge-induction hypothesis. F. gen. Physiol., Vol. 43, Supplement I, pp. I49-74.

LubIN, M. \& SCHNEIDER, P. B., I957. The exchange of potassium for caesium and rubidium in frog muscle. F. Physiol., Vol. 138, pp. 140-55.

Margaria, R., I93I. The osmotic changes in some marine animals. Proc. roy. Soc., B, Vol. 107, pp. 606-24.

Mullins, L. J., I959. The penetration of some cations into muscle. F. gen. Physiol., Vol. 42, pp. 817-29. 
Mullins, L. J., 1960. An analysis of pore size in excitable membranes. F. gen. Physiol., Vol. 43, Supplement I, pp. I05-17.

Mullins, L. J. \& Moore, R. D., 1960. The movement of thallium ions in muscle. F. gen. Physiol., Vol. 43, pp. 759-73.

NAGEL, H., I934. Die Aufgaben der Exkretionsorgane und der Kiemen bei der Osmoregulation von Carcinus maenas. Z. vergl. Physiol., Bd. 2I, pp. 468-9I.

Relman, A. S., Lambie, A. T., Burrows, B. A. \& Roy, A. M., 1957. Cation accumulation by muscle tissue: The displacement of potassium by rubidium and cesium in the living animal. F. clin. Invest., Vol. 36, pp. I249-56.

RoBERTSON, J. D., 1939. The inorganic composition of the body fluids of three marine invertebrates. F. exp. Biol., Vol. 16, pp. 387-97.

-1953. Further studies on ionic regulation in marine invertebrates. F. exp. Biol., Vol. 30, pp. 277-96.

- 1960 . Ionic regulation in the crab Carcinus maenas (L.) in relation to the moulting cycle. Comp. Biochem. Physiol., Vol. I, pp. 183-212.

SHAw, J., 1958. Further studies on ionic regulation in the muscle fibres of Carcinus maenas. F. exp. Biol., Vol. 35, pp. 902-19.

StoBbart, R. H., 1959. Studies on the exchange and regulation of sodium in the larva of Aëdes aegypti (L.). I. The steady state exchange. F. exp. Biol., Vol. 36, pp. 64I-53.

WebB, D. A., I940. Ionic regulation in Carcinus maenas. Proc. roy. Soc., B, Vol. I29, pp. 107-36.

WHITTEMBURY, G., I960. Ion and water transport in the proximal tubules of the kidney of Necturus maculosus. F. gen. Physiol., Vol. 43, Supplement I, pp. 43-56. 